\title{
Central and peripheral control of food intake
}

\author{
${ }^{1,2}$ AbDalla MMI \\ ${ }^{1}$ Physiology Department, Faculty of Medicine, MAHSA University, Malaysia; \\ 2Physiology Department, Faculty of Medicine, Minia University, Egypt \\ E-mail:dr.mona@mahsa.edu.my
}

\begin{abstract}
The maintenance of the body weight at a stable level is a major determinant in keeping the higher animals and mammals survive. The body weight depends on the balance between the energy intake and energy expenditure. Increased food intake over the energy expenditure of prolonged time period results in an obesity. The obesity has become an important worldwide health problem, even at low levels. The obesity has an evil effect on the health and is associated with a shorter life expectancy. A complex of central and peripheral physiological signals is involved in the control of the food intake. Centrally, the food intake is controlled by the hypothalamus, the brainstem, and endocannabinoids and peripherally by the satiety and adiposity signals. Comprehension of the signals that control food intake and energy balance may open a new therapeutic approaches directed against the obesity and its associated complications, as is the insulin resistance and others. In conclusion, the present review summarizes the current knowledge about the complex system of the peripheral and central regulatory mechanisms of food intake and their potential therapeutic implications in the treatment of obesity.
\end{abstract}

Key words: food intake, gastrointestinal hormones, energy balance, satiety signals, adiposity signals

The maintenance of the body weight at a stable level is a major determinant in keeping the higher animals and mammals survive (Jequier and Tappy 1999). As a compensatory mechanism, hunger increases and energy expenditure decreases the weight loss. However, opposite responses are triggered when body weight increases. Body weight can change only when energy intake is not equal to energy expenditure over a given period of time (Bray et al. 2012). A complex physiological control system is involved in the maintenance of the energy balance. This system includes afferent signals from the periphery about the state of the energy stores and efferent signals that affect the energy intake and expenditure (Sandoval et al. 2008). This regulatory system is formed by multiple interactions between the gastrointestinal tract
(GIT), adipose tissue, and the central nervous system (CNS). It is influenced by behavioral, sensorial, autonomic, nutritional, and endocrine mechanisms (Boguszewski et al. 2010).

\section{Satiety and adiposity signals}

The food intake control includes a short-term regulation, which determines the beginning and the end of a meal (hunger and satiation) and the interval between the meals (satiety) and a long-term regulation with factors (signals of adiposity), which help to regulate the body energy depots (Cummings and Overduin 2007).

The satiation means a suppression of the hunger and termination of the food intake after ingestion of

Corresponding author: Mona Mohamed Ibrahim Abdalla, M.D., Jalan Elmu, Off Jalan University, 59100, Kuala Lumpur, Malaysia; phone: 006-018-2024126; fax: 6037965 2688; e-mail: monaalbetar@yahoo.com, dr.mona@mahsa.edu.my. 
a certain amount of food (Smith 1998). The mechanisms controlling satiation determine the size of the meal. Satiety is a period of time between the meals with no hunger (Strubbe and Woods 2004). This time period is variable and its termination coincides with the refeeling of the hunger accompanied by the consumption of the next meal, thus resuming the cycle of the food intake (Hargrave and Kinzig 2012) (Figure 1).

The mechanisms, which control the size of the meal (satiation) and those controlling the intervals between the meals (satiety), differ (de Graaf et al. 2004; Benelam 2009). The satiation is determined by physiological and psychological mechanisms, which trigger the afferent signals to brain from multiple sites in the GIT, including the stomach, the proximal small intestine, the distal small intestine, and the colon (Ritter 2004; Keenan et al. 2015).

The satiety is affected by short-term signals from GIT (Zac-Varghese et al. 2010) and long-term signals from the body energy store (Woods 2005). The signals from GIT are transmitted primarily via the vagal and spinal nerves to the nucleus of the solitary tract (NTS). Transection of all the gut sensory vagal fibers has been shown to increase the meal size and its duration (Schwartz 2000; Powley et al. 2005). However, the stimulation of the vagus nerve did not result in a weight gain (Koren and Holmes 2006). The long-term signals (adiposity signals) reach the arcuate nucleus (ARC) via the median eminence or by crossing the blood-brain barrier (BBB). There exists, however, a large number of integrations and convergences between these signals mediated by neural connections between the ARC nucleus, NTS, and the vagal afferent fibers (Boguszewski et al. 2010).

\section{The hypothalamus role in the food intake control}

The hypothalamus plays a major role in the control of the appetite. In the hypothalamus, afferent signals from the gut and brain stem relied and efferent signals for the food intake control are processed. Within the hypothalamus, there are many nuclei and neuronal circuits involved in the food intake regulation, such as the ARC, a key hypothalamic nucleus in the appetite control, the paraventricular nucleus (PVN), the dorsomedial nucleus (DMN), the ventromedial nucleus $(\mathrm{VMN})$, and the lateral hypothalamic area (LHA) (Wynne et al. 2005).

Arcuate nucleus (ARC) contains two neuronal populations with opposing effects on the food intake, i.e. neurons, which stimulate the food intake co-expressing neuropeptide Y (NPY) and agouti re- lated peptide (AgRP), and neurons, which suppress the feeding co-expressing pro-opiomelanocortin (POMC) and cocaine- and amphetamine-regulated transcript (CART). Both types of the neurons project to the hypothalamic areas, which are involved in the control of appetite including the DMN, PVN, and LHA (Suzuki et al. 2010) (Figure 2).

Neuropeptide $\mathrm{Y}$ is the most abundant neurotransmitter in the brain. The hypothalamic NPY neuropeptide levels increase during the fasting and decrease after the feeding (Wynne et al. 2005). The NPY integrates a large family of peptides that includes peptide YY (PYY) and pancreatic polypeptide (PP), the effects of which are mediated via the six G-protein-coupled receptors named Y1 to Y6. The orexigenic effect of NPY is mediated by stimulation of the hypothalamic Y1R and Y5R, in addition to the local inhibition of the POMC neurons in the ARC. In addition, AgRP acts as a selective antagonist at MC3R and MC4R in the PVN (Suzuki et al. 2010).

Activation of NPY may explain the easy recovery of weight observed in the obese individuals undergoing treatment, since weight reduction leads to a decrease in the leptin, activation of NPY, and consequently to hyperphagia and reduced energy expenditure (Boguszewski et al. 2010). Regain of the weight, following the weight loss, can be a result of the modified adipose tissue cellularity, endocrine function, and energy metabolism (Ochner et al. 2013).

The anorexigenic effect of POMC has been proven by an increase in the food intake and adiposity as a result of POMC gene mutations in humans (Krude

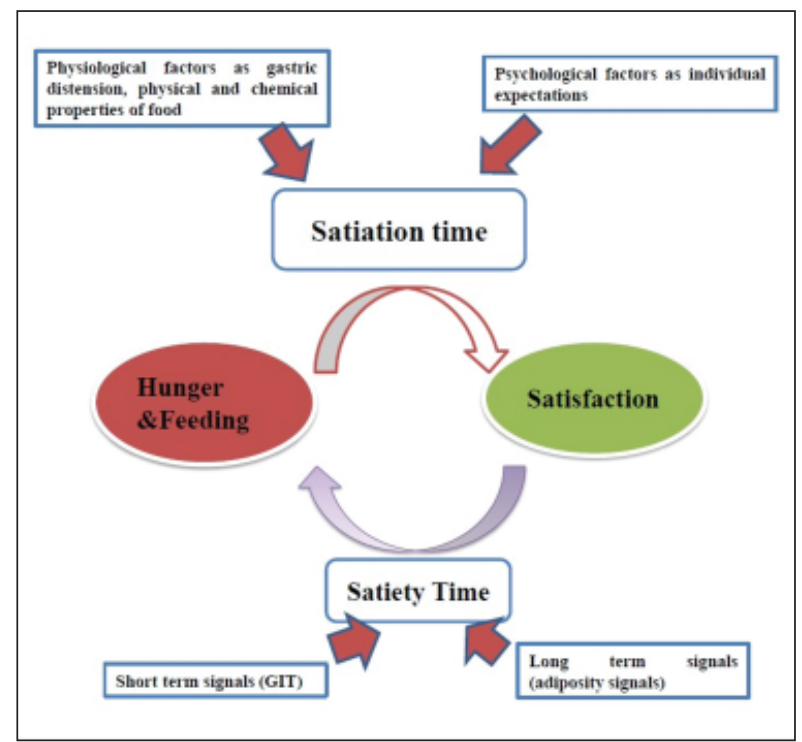

Figure1. Food intake cycle. 


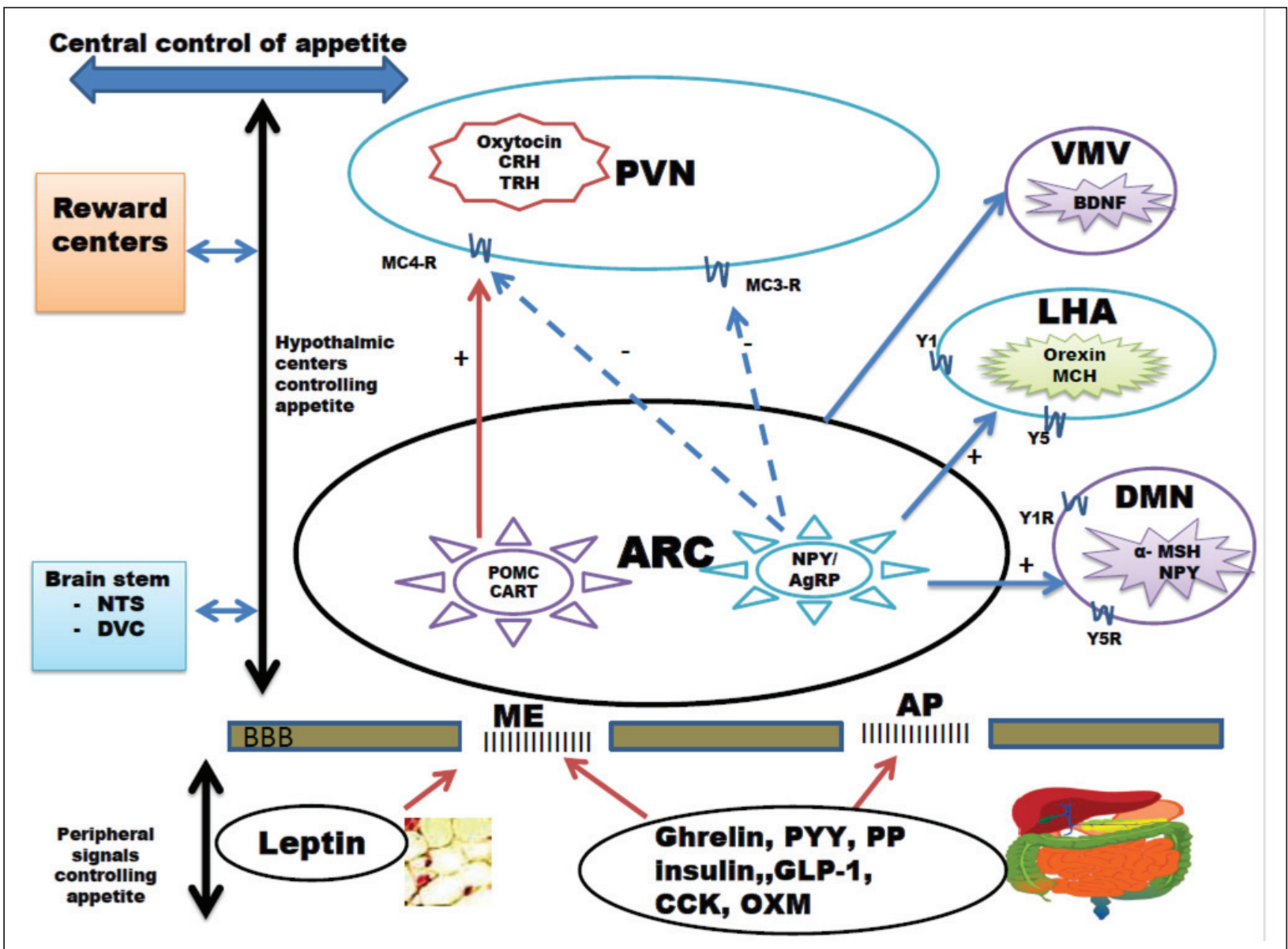

Figure 2. Short and long signals for food intake control. Abbreviations: ARC - arcuate nucleus; NPY/AgRP - neuropeptide Y and agouti related peptide; POMC/CART - pro-opiomelanocortin and cocaine- and amphetamine-regulated transcript; PVN - paraventricular nucleus; LHA - lateral hypothalamic area; DMN - dorsomedial nucleus; VMN - ventromedial hypothalamic nucleus; ME - median eminence; AP - area postrema; GLP-1 - glucagon-like peptide-1; CCK - cholecystokinin; PP - pancreatic polypeptide; PYY - peptide YY; OXM - oxyntomodulin; BBB - blood-brain barrier; MCH - melanin-concentrating hormone; $\alpha$-MSH - alpha melanocyte stimulating hormone; BDNRF - brain derived neurotrophic factor; CRH - corticotrophin releasing hormone; NTS - nucleus tractus solitaries; DVC - dorsal vagal complex; TRH - thyroid releasing hormone; MC4-R - melanocortin receptor 4; MC3-R - melanocortin receptor 4; Y1R \& Y5R - neuropeptide Y receptors 1 \& 5

et al. 1998) and gene deletion in canine (Raffan et al. 2016). In the ARC nucleus, the cleavage of POMC results in the production of melanocortin peptides including adrenocorticotropic hormone (ACTH) and a-melanocyte-stimulating hormone ( $\alpha-\mathrm{MSH})$ that exert their effects by binding to G-protein coupled melanocortin receptors (MC-Rs). From five, two melanocortin receptors are expressed in the brain, MC4-R and MC3-R. Hyperphagia and obesity result from the targeted deletion of MC4-R in mice (Huszar et al. 1997). The higher fat content that have been noticed in MC3-R knockout mice (Chen et al. 2000) reflects the importance of these two receptors in controlling the appetite. The inhibitory effect of the melanocortinergic neurons is antagonized by AgRP at MC4-R and MC3-R (Bagnol et al. 1999). The products of POMC cleavage, the five different subtypes of G-protein-coupled receptors, and the endogenous antagonists, AgRP and Agouti constitute the melanocortin system that is involved in many important physiological processes. In addition to food intake, the melanocortin system is involved in the regulation of pigmentation, adrenocortical steroidogenesis, natriuresis, erection, and exocrine secretion (Cone 2005; Wynne et al. 2005).

Majority of the neurons that express POMC also co-express CART mRNA. The fasting decreases CART expression (Kristensen et al. 1998). Animal studies have shown a decrease in the food intake upon the intracerebroventricular (ICV) administra- 
tion of CART (Aja et al. 2001; Rohner-Jeanrenaud et al. 2002) and its increase after ICV injection of CART antiserum (Kristensen et al. 1998). However, recent studies have shown an increase in the food intake after injection of CART into the hypothalamic nuclei in streptozotocin-diabetic rats (Hou et al. 2010). This suggests that CART can be orexigenic or anorexigenic, based on the neural circuit that is stimulated. It has been suggested that decreased expression of CART mRNA in ARC and PVN regions may contribute to the development of high-fat diet-induced obesity in mice. In addition, CART in the DMN and LH may be involved in the activation of the orexigenic effect ( $\mathrm{Yu}$ et al. 2008).

Neurotensin (NT), a peptide expressed in the brain and GIT, plays a role in the regulation of food intake as evidenced by the inhibition of the food intake following the central and peripheral NT administration (Ratner et al. 2016). Transient increase in the food intake has been shown following pharmacological NT antagonism in a rat Roux-en-gastric bypass model (Ratner et al. 2016). It has been shown that peripheral NT administration inhibits the food intake by increasing the POMC mRNA in the ARC (Ratner et al. 2016). The anorexigenic effect of NT is mediated by neurotensin receptor-1 (Ntsrl), as it has been evidenced by Kim and Mizuno (2010). Other peptides that act on Ntsrl and inhibit food intake include neuromedin U (Kim and Mizuno 2010) and xenin, a peptide that is released from the small intestine (Sterl et al. 2016).

The hypothalamic paraventricular nucleus (PVN) contains several neurons that secrete anorexigenic substances such as corticotropin-releasing hormone $(\mathrm{CRH})$, oxytocin, and thyrotropin-releasing hormone (TRH). Each of these peptides acts to decrease food intake, increase the metabolic rate, or both (Morton et al. 2012; Blevins et al. 2015; Moore et al. 2015). The $\mathrm{CRH}$ is a 41 amino acid peptide, which is widely distributed throughout the brain, but is particularly abundant in the medial parvocellular division of the PVN (Sawchenko et al. 1985). In addition to its role in controlling the activity of the pituitary adrenal axis, CRH controls the food intake too. Within the brain, $\mathrm{CRH}$ with its two receptor types, CRH type 1 (CRH1-R) and CRH type $2 \alpha$ (CRH2 $\alpha-\mathrm{R})$, its binding protein, and its closely related peptide urocortin, forms a network of neuronal pathways that is capable of interacting with other circuitries controlling the food intake (Mastorakos and Zapanti 2004). It has been shown that CRH mediates the anorexigenic effect of $\alpha-\mathrm{MSH}$ in fish (Matsuda et al. 2008) and ELABELA in the adult mouse (Santoso et al. 2015). ELABELA, a novel hormone consisting of 32 amino acid peptides, found in humans and other vertebrates, is considered to play an important role in the circulatory system. It has been shown that ICV injection of ELABELA reduces food intake and activates the arginine vasopressin (AVP) and CRH neurons in the PVN in a dose dependent manner (Santoso et al. 2015).

A defect in the synthesis and release of the CRH has been implicated in the development of the obesity in laboratory animals (Mastorakos and Zapanti 2004). Moore et al. (2015) have reported a beneficial effect of CRH1-R antagonism in the attenuation of the stress-induced consumption of palatable diets in female rhesus monkeys. It has been suggested that anorexigenic effect of $\mathrm{CRH}$ is conferred by CRH1R (Hotta et al. 1999). However, it has been observed that $\mathrm{CRH}$ is able to decrease the food intake in CRH1R knockout mice as much as in wild type littermates suggesting that both CRH1-R and CRH2-R may mediate the food intake inhibitory effect of $\mathrm{CRH}$ and urocortin but at different time course (Sekino et al. 2004).

Oxytocin, a hypothalamic peptide, is released into the circulation through the posterior pituitary and also directly acts on the central nervous receptors. In addition to its role in regulation of reproductive functions, such as mother-infant interaction and lactation, it is a potent modulator of social behaviors including attachment and sexual behavior (MeyerLindenberg et al. 2011). Moreover, animal studies and pilot experiments in humans have indicated that oxytocin might have a role in the regulation of eating behavior and metabolism in normal weight as well as with diet-induced obesity. Oxytocin administration in animals and humans inhibits food intake, increases energy expenditure, and reduces glucose levels (Morton et al. 2012; Ott et al. 2013; Blevins et al. 2015; Lawson et al. 2015). Interestingly, there are experiments, which suggest that the metabolic effects of oxytocin may be even enhanced in diet-induced obese in comparison to control weight (Thienel et al. 2016) with absent or minimal side effects. This makes oxytocin a promising pharmacological intervention in obesity (Blevins and Baskin 2015; Zhang et al. 2013). A recent study has shown that central oxytocin acts via an oxytocin receptor that is expressed in the nucleus accumbens core to decrease food intake driven by hunger and reward in rats offered a meal in a non-social setting (Herisson et al. 2016).

Galanin-like peptide (GALP) is a neuropeptide expressed in several brain areas including hypothalamic nuclei involved in the appetite regulation such 
as ARC, PVN, and median eminence (Wodowska and Ciosek 2015). GALP seems to be a promising peptide in the obesity treating. GALP administration has been effective in ameliorating the obesity in mice, where it has been shown that brain uptake of GALP is higher after intranasal than intravenous administration (Hirako et al. 2016; Kageyama et al. 2016). Administration of GALP in mice, but not rats, resulted in an acute orexigenic effect that may be explained by an NPY input to GALP neurons from the ARC NPYcontaining neurons and orexin-containing neurons in LHA, in addition to fibers that project from GALP neurons to orexin and melanin-concentrating hormone $(\mathrm{MCH})$ ones in the LHA (Takenoya et al. 2005). However, this orexigenic effect was transient and followed by a chronic anorexigenic effect and decrease of the body weight. It has been suggested that GALP expression is regulated by leptin and insulin as evidenced by the presence of leptin receptors in more than $85 \%$ of GALP neurons (Hirako et al. 2016). The expression of GALP in the brain has been found to be increased after administration of the leptin in fasted rats as compared with controls (Lawrence and Fraley 2011). GALP expression has been found to be restored in diabetic rats after insulin administration (Fraley et al. 2004).

The lateral hypothalamic area (LHA). Orexin A and $\mathrm{B}$, a pair of neuropeptides, are produced in cells located in the hypothalamic lateral and perifornical areas. Orexin A has been found to enhance the food intake when injected into certain hypothalamic nuclei such as LHA, PVN, DMN, and the perifornical area. However, orexin $B$ has been found to be ineffective when injected to any of the hypothalamic nuclei (Dube et al. 1999). Hypocoretin-1 (HC, Orexin A) is a neuropeptide that is involved in the regulation of many physiological functions, such as sleep, appetite, and arousal. Recently, a study on rats has shown an increase in the food consumption after intranasal administration of HC (Dhuria et al. 2016). In addition to orexin expressing cells, LHA contains $\mathrm{MCH}$ expressing cells that extend in a wider area. These two types of cells are targets for NPY and AgRP projections coming from the ARC (Broberger et al. 1998).

The ventromedial nucleus (VMN). In addition to the large population of glucoresponsive neurons in the VMN, the brain-derived neurotrophic factor (BDNF) is also highly expressed. Central infusion of BDNF reduces food intake and induces weight loss in rats (Pelleymounter et al. 1995). The VMN receives NPY, AgRP, and POMC neuronal projections from the ARC and it is thought that POMC neurons from the ARC play a role in activating BDNF neurons in
VMN to decrease the food intake (Xu et al. 2003).

The dorsomedial nucleus (DMN) contains a high level of NPY and $\alpha-\mathrm{MSH}$ terminals originating in the ARC. From DMN, $\alpha-M S H$ fibers project to the TRHcontaining neurons in the PVN (Mihaly et al. 2001). Destruction of the DMN results in hyperphagia and obesity (Bernardis and Bellinger 1986).

\section{Role of the brainstem}

The dorsal vagal complex (DVC), located within the brainstem, is a crucial in the interpretation and relaying of peripheral signals from the gut to the hypothalamus. The DVC consists of the dorsal motor nucleus of the vagus (DVN), the area postrema (AP), and the NTS within which POMC neurons exist (Schwartz 2010). Receptors for a variety of hormones controlling food intake have been found to be expressed in the brainstem vagal afferent neurons including cholecystokinin (CCK) $1 \mathrm{R}$ and CCK $2 \mathrm{R}$ at which both CCK and gastrin act (Moriarty et al. 1997), insulin receptors, GLP-1 (Nakagawa et al. 2004) and GLP-2R (Nelson et al. 2007), growth hormone secretagogue receptor (GHS)-R1 at which ghrelin acts (Date et al. 2002), the orexin receptor, OX-R1 (Burdyga et al. 2003), and leptin (Burdyga et al. 2002).

\section{Role of the reward system}

Different brain circuits involved in the reward, as the hippocampus, amygdala, pre-frontal cortex, and midbrain, have been found to be activated by food and food-related cues (Palmiter 2007; Kenny 2011). Dopamine is a neurotransmitter that is released from the neurons in the mesolimbic system and mediate emotions and pleasure (reviewed by Nutt et al. 2015). It has been demonstrated that with food intake dopamine release is enhanced in the circuits that mediate the pleasurable aspects of the eating (Volkow et al. 2011). However, decreased body weight after chronic food deprivation has been shown to be associated with a decrease of dopamine levels (Pothos et al. 1995). This suggests that increased food intake after chronic food deprivation and weight loss may represent a compensatory mechanism to restore the baseline dopamine levels (Cota et al. 2006).

The endogenous opioid and endocannabinoid systems play important role in the reward-related feeding (Pomorska et al. 2016). The endogenous opioid peptides such as $\beta$-endorphins derived from POMC, which is a precursor of opioids, bind to opioid receptors that are distributed in the hypothalamic regions controlling the food intake (reviewed by Kenny 2011). 
Some studies have shown that infusions of $\mu$-opioid receptor agonists stimulate feeding behavior in rats, while opioid receptor antagonists infused decrease the consumption of the preferred food without affecting the intake of the less palatable alternatives (reviewed by Goodman 2008). In addition, systemic injection of a $\mu$-opioid antagonist prevents the stimulatory effect of palatable food on dopamine release in the nucleus accumbens, which confirms the excitatory effects of opioids on the dopamine system (Tanda and di Chiara 1998).

\section{Role of the endocannabinoid system}

The plant-derived cannabinoids such as $\Delta^{9}$-tetrahydrocannabinol (THC) as well as their synthetic analogues, act in the organism by activating specific cell-surface receptors that are normally engaged by a family of endogenous ligands; the endocannabinoids. The first endocannabinoid discovered was named anandamide (AEA), the amide of arachidonic acid (AA) and ethanolamine (Et) (Devane et al. 1992). A second arachidonic-acid derivative is the 2-arachidonoylglycerol (2-AG) that binds to cannabinoid receptors was subsequently described (Mechoulam et al. 1995).

Endocannabinoids are produced by a variety of cell types including endothelial cells (Gauthier et al. 2005), adipocytes (Pagano et al. 2008), glial cells (Gonthier et al. 2007), macrophages (Di Marzo et al. 1999), and Purkinje cells (Maejima et al. 2001). The endocannabinoid system (ECS) consists of the endogenous cannabinoid ligands, the enzymatic machinery involved in their synthesis uptake and degra-

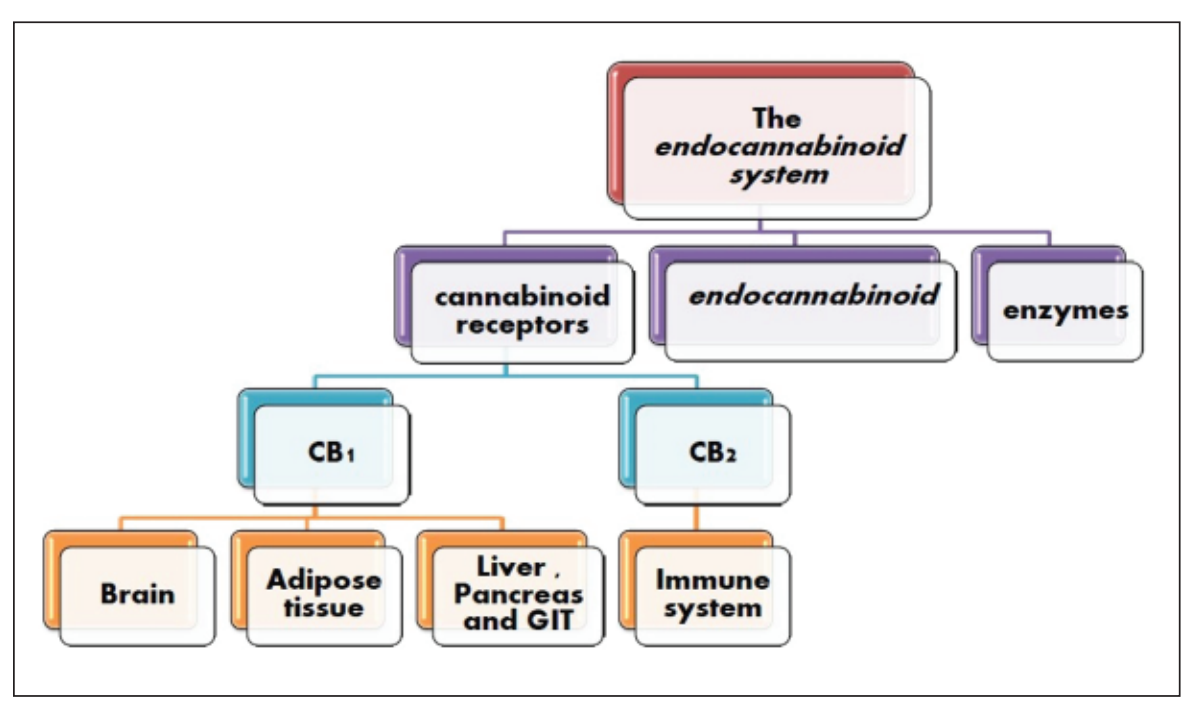

Figure 3. The endocannabinoid system. dation, the G-protein-coupled cannabinoid receptors type 1 and 2 (CB1 and CB2) (Kogan and Mechoulam 2006; Quarta et al. 2011). CB1 has been found to be widely and abundantly distributed in tissues involved in the energy homeostasis, including the hypothalamus, brainstem, mesolimbic region, and peripheral tissues such as the GIT, fat, liver, muscle, thyroid, and pancreas (Matias et al. 2006). CB2 is well known in his immune modulatory effect (Cabral and GriffinThomas 2009). However, recently it has been found that CB2 plays a role in the energy homeostasis and food intake (Verty et al. 2015) (Figure 3).

The ECS is involved in the regulation of food intake and energy balance as evidenced by the following: 1) binding of endocannabinoids to CB1 receptors results in an increased appetite, weight gain, lipogenesis, and lower insulin sensitivity (Horvath 2003); 2) an increased food intake after central administration of cannabinoids mediated by CB1 activation (Jamshidi and Taylor 2001; Verty et al. 2005) and its suppression by blocking the cannabinoid receptor that has been found to have a direct participation of sympathetic nervous system, ghrelin, or leptin (Alen et al. 2013; Silvestri and Di Marzo 2013); 3) increased endocannabinoid hypothalamic levels in rodents with diet-induced or genetic obesity (Quarta et al. 2011). The endocannabinoids increase the production of the hypothalamic appetite stimulating transmitters and reduce the production of the appetite-suppressing signals. In the reward center of the mesolimbic region, the endocannabinoids promote the motivation to eat palatable food (Di Marzo and Matias 2005).

Food intake has been found to be suppressed by genetic deletion or pharmacological CB1 blockade in the lean and obese starved animals (Verty et al. 2009; Quarta et al. 2010; Quarta et al. 2011; Rorato et al. 2013). However, other studies have shown that CB1 blockade may result in a food intake independent decrease in fat mass mainly through lipolysis (Jbilo et al. 2005; Nogueiras et al. 2008; Quarta et al.2010). As a consequence, CB1 blockade has been shown to be effective in ameliorating the obesityrelated metabolic disorders (Cota et al. 2003; Ravinet Trillou et al. 2004; Quarta et al. 2011). 
The activation of ECS has been found to promote energy storage (Bermudez-Silva et al. 2010; Quarta et al. 2010; Bermudez-Silva et al. 2012). Physiologically, ECS is activated in response to stressful stimuli helping the affected tissues to restore their steady state (Pagotto et al. 2006). Ingestion of food, CCK and other gastric peptides decrease the activity of the ECS. In contrast, increased circulating levels of ghrelin in situations of the food deprivation are associated with higher endocannabinoid activity, suggesting that the orexigenic effect of ghrelin occurs, at least in part, by activation of the endocannabinoid system (Boguszewski et al. 2010). Leptin produced from the adipose tissue reduces the levels of endocannabinoids due to interference with 2-AG synthesis and increased anandamide degradation (Di Marzo and Matias 2005).

Is the over-activity of ECS a cause of obesity?

The sustained hyperactivity of the ECS could lead to hyperphagia with a progressive and excessive accumulation of fat and subsequent development of obesity (Ravinet Trillou et al. 2004), insulin resistance, and disturbed lipid profile (Foster-Schubert and Cummings 2006). Obesity has been found to be associated with a dysregulation of the ECS. CB1 has been found to be less in obese and returned to the normal after weight loss (Bennetzen et al. 2011). Blocking of CB1 in humans using rimonabant, as a treatment for obesity, resulted in psychiatric side effects, which resulted in withdrawal of the drug (Lee et al. 2009). However, targeting the peripheral CB1 receptors has been found to safely alleviate the cardio-metabolic disorders associated with the obesity (Tam et al. 2010).

The effectiveness of $\mathrm{CB} 1$ receptor blockade in decreasing body weight and amelioration of the obesity related metabolic disorders may be mediated by elimination of ECS effects on the appetite, increase in adiponectin levels, which is thought to result in increased fat metabolism and an improvement in glucose metabolism (Scheen et al. 2006) and increase in the mitochondrial biogenesis in white adipocytes by inducing the expression of nitric oxide (NO) produced by endothelial NO synthase (eNOS), which is linked to the prevention of high-fat diet-induced fat accumulation, without concomitant changes in food intake (Tedesco et al. 2008).

\section{Role of the gastrointestinal tract peptides}

The gastrointestinal (GI) tract is the largest endocrine organ in the body where many hormone genes are expressed and bioactive peptides are produced (Rehfeld 1998). Many of these hormones and peptides are involved in the peripheral control of the food intake by controlling the initiation and termination of the meal. Besides the role of peptides in satiation and satiety, gastric distension has a satiating effect that forms the basis of gastric balloon use in humans as a treatment for obesity (Martin et al. 2007).

Cholecystokinin (CCK) was the first gut hormone shown to modulate the food intake (Bray and York 1972). CCK is secreted postprandial from I cells of the small intestine into the circulation with a plasma half-life of a few minutes. CCK levels rise rapidly reaching a peak within 15 minutes after a meal. It is also reported to reduce food intake in humans and rodents (Liddle et al. 1985). The action of CCK is mediated by two CCK receptor subtypes: CCK1 and CCK2, which are widely distributed in the brain including the brainstem and the hypothalamus (Moran et al. 1998). The anorectic action of CCK has been found to be mostly mediated through CCK1R on vagal afferents (Moran et al. 1997). There are various forms of CCK with various effects on the meal size and the intervals between meals. While CCK 58 and CCK- 8 both stimulate satiation, thereby reducing meal size, CCK-58 consistently exerts a satiety effect (Overduin et al. 2014). Similar results have been reported with CCK-33, which has been found to reduce the food intake by prolonging the inter-meal interval (Washington et al. 2011; Lateef et al. 2012).

Peptide tyrosine tyrosine (PYY) is a member of the pancreatic polypeptide (PP) family (Lin et al. 2004). There are two circulating forms of PYY released by L cells in the distal gut: PYY (1-36) and PYY (3-36). PYY (3-36), the major circulating form, is produced by cleavage of the N-terminal TyrosineProline residues from PYY (1-36) by the enzyme dipeptidyl-peptidase-IV (DPP-IV) (Wynne et al. 2005). Currently, the DPP-IV inhibitors are being evaluated for their effects on the obesity and metabolic traits (Martin et al. 2015).

PYY (3-36) binds with highest affinity to the hypothalamic Y2R causing a reduction in food intake. It also binds to other Y receptors, although with much lower affinity. In addition to PYY's anorectic effect on food intake, it also increased the energy expenditure (Boey et al. 2008) and delayed gastric emptying in mice (Talsania et al. 2005). The low level of PYY in obese subjects and their blunt increase after a meal possibly results in impaired satiety and hence greater food intake (le Roux et al. 2006). However, this was not supported by the findings of another study that has shown no differences in the levels of PYY between lean and the obese (Pfluger et al. 2007). Weight regain after Roux-en-Y gastric bypass (RYGB) has been 
found to be attributed to the failure to sustain a high level of PYY indicating that combining RYGB with pharmacologic stimulation of PYY secretion in patients after RYGB who exhibit inadequate PYY concentration may increase long-term success of surgical weight reduction in morbidly obese adults (Meguid et al. 2008).

Pancreatic polypeptide (PP) is a hormone released from the pancreas in response to food ingestion. PP plasma levels are reduced by obesity and increased by anorexia nervosa. The peripheral administration of PP has been shown to decrease the food intake in rodents and humans (Batterham et al. 2003; Jesudason et al. 2007). PP is thought to reduce food intake through the following mechanisms 1) stimulation of Y4 and Y5 receptors in the dorsal vagal complex, including the area postrema (AP), the nucleus of the solitary tract (NTS) and the dorsal motor nucleus of the vagus (DMV) (Whitcomb et al. 1997; Lin et al. 2009); 2) sending anorexigenic signals via the brainstem and hypothalamic neuropeptides (Hankir et al. 2011); 3) modulation of the expression of other peripheral peptides such as ghrelin, and 4) delay in gastric emptying that seemed to occur only in animal models and not in humans. The anorectic effects of PP and PYY (3-36) are abolished in abdominal vagotomised rats, suggesting that PP and PYY (3-36) induce anorexia via vagal afferent nerves (Iwasaki et al. 2013).

Enterostatin and apolipoprotein A-IV. Enterostatin is a peptide secreted from the exocrine pancreas in response to fat intake to facilitate its digestion (Cummings and Overduin 2007). Both peripheral and central enterostatin administrations have been found to decrease dietary fat intake in animals, conversely enterostatin-receptor antagonists have been found to do the opposite (Okada et al. 1992). Apolipoprotein A-IV (APO AIV) is a glycoprotein secreted from the intestine in response to fat absorption and chylomicron formation to be used in packaging of digested lipids in transit through lymphatic to blood. It has been hypothesized that APO AIV represents a link between the short- and long-term regulations of lipid-related energy balance (Qin and Tso 2005) based on the following findings: 1) APO AIV is produced in the hypothalamic arcuate nucleus (Tso et al. 2004) and 2) exogenous administration of APO AIV has been found to decrease meal size, food intake, and weight gain in rats, whereas APO AIV-specific antibodies have been found do the opposite (Fujimoto et al. 1993).

Glucagon-like peptide-1 (GLP-1). The pro-glucagon gene is cleaved into different products by the en- zymes convertase 1 and convertase 2 , a process that varies among the tissues. In the pancreas, the main product of this cleavage is glucagon, whereas in the intestine the GLP-1 and GLP-2. GLP-1 is released into the circulation after meals, physiologically acting as an incretin that promotes increased pancreatic insulin secretion and consequently influences the glucose homeostasis (Holst 2004).

DPP-IV degradation and renal clearance rapidly inactivate and remove GLP-1 from the plasma circulation, resulting in a half-life of 1-2 minutes (Mentlein et al. 1993). GLP-1 has two biologically active forms, GLP-1 (7-37) amide and GLP-1 (7-36) amide, the latter being the major circulating form in humans. GLP-1R expression is widely distributed particularly in the brain, GIT, and pancreas (Baggio and Drucker 2014). Circulating GLP-1 levels rise after a meal and fall in the fasted state. GLP-1 reduces food intake (Parker et al. 2013), suppresses glucagon secretion (Hare 2010), and delays gastric emptying (Little et al. 2006).

Oxyntomodulin (OXM) is another product of the proglucagon gene, which is released from the intestinal cells into the circulation in proportion to caloric intake (Ghatei et al. 1983). OXM has been found to reduce the food intake and promote increased energy expenditure resulting in negative energy balance that supports the role of oxyntomodulin as a potential anti-obesity therapy (Cohen et al. 2003; Wynne et al. 2006). The most likely mechanism of OXM action on energy homeostasis is through its binding to the GLP-1 receptor as GLP-1 receptor antagonists have been found to reduce the food intake (Dakin et al. 2004). Although OXM binds the GLP-1 receptor with lower affinity than GLP-1 by approximately 50 fold less strongly than GLP-1, they are equally effective in causing anorexia. Thus, differences in the biological effects of OXM and GLP-1 may be due to variations in the tissue penetration, degradation, or intracellular signaling pathways (Fehmann et al. 1994; Baggio et al. 2004).

Glucagon is produced by alpha cells of the pancreatic islets. In contrast to GLP-1 and insulin, hypoglycemia causes an increase in the glucagon secretion resulting in hepatic glycogenolysis. Peripheral as well as central administration of glucagon in rats reduced food intake and meal size in addition to reducing body weight gain (Geary et al. 1993; Honda et al. 2007). Combination of glucagon and GLP-1 agonists has been found to be beneficial as a treatment of obesity rodents have been demonstrated (Pocai et al. 2009) as GLP-1 prevented the hypoglycemia induced by glucagon (Parker et al. 2013). 
Insulin and amylin. Insulin, a peptide secreted from beta cells of the pancreas after a meal and its amount along with leptin has been found to be directly proportional to white fat (Considine et al. 1996) that may reflect the important role of both as an adiposity signals from adipose tissue to the hypothalamic centers controlling energy balance. Although there is a controversy in the issue weather insulin can cross the blood brain barrier and weather it is synthesized by the brain itself (Woods et al. 2003; Gerozissis 2004). It has been found that central administration of insulin caused a decrease in food intake and weight loss in animals (Woods et al. 1979; Riedy et al. 1995) whereas opposite effect has been found when insulin antibodies were administered in or near the mediobasal hypothalamus (McGowan et al. 1992) where insulin receptors are highly expressed (Halmos and Suba 2011).

Amylin is a peptide co-secreted with insulin, inhibits gastric emptying, gastric acid and glucagon secretions, and reduces food intake and meal size in animals (Young and Denaro 1998). The anorectic action of amylin has been found to be mediated by decreasing the expression of orexigenic neuropeptides (Lutz 2009). The effect of chronic administration of amylin in increasing energy expenditure has been demonstrated (Wielinga et al. 2007). Acute administration of amylin agonist, salmon calcitonin but not amylin significantly stimulated energy expenditure in fasted animals (Roth et al. 2006).

Ghrelin is the only known orexigenic gut peptide secreted mainly from the stomach. The pre-prandial elevation of ghrelin levels and its fall after meals led to the notion that ghrelin is a 'hunger' hormone responsible for meal initiation. Ghrelin is involved in short-term regulation of the food intake and longterm regulation of bodyweight through decreasing fat utilization (Castaneda et al. 2010). The effect of ghrelin on food intake is mediated through the growth hormone secretagogue receptor la (GHS-R1a), which is highly expressed in the hypothalamic cell populations that regulate the feeding and the body weight homeostasis. This was evidenced by lack of the orexigenic effect of ghrelin in GHS-R knocked out mice (Sun et al. 2004). Ghrelin's orexigenic effect is mediated by specific modulation of AgRP/NPY neurons in the ARC without demonstrated change in the mRNA levels of the other feeding-promoting neuropeptides such as melanocyte stimulating hormone $(\mathrm{MCH})$ and pre-pro-orexin (OX) (Cowley et al. 2003). Recent data have indicated that the orexigenic effect of ghrelin is mediated by its modulation of the hypothalamic adenosine monophosphate (AMP)-activated protein kinase (AMPK) enzyme activity (Kola et al. 2008). The detection of the ghrelin receptors on the vagal afferent neurons in the rat suggests that ghrelin signals from the stomach are transmitted to the brain via the vagus nerve (Date 2012). However, the findings regarding effect of vagatomy on the orexigenic effect of ghrelin in animal models and humans is not universal. The vagal afferents cut was not necessary for the orexigenic effect of the peripherally injected ghrelin in rats (Arnold et al. 2006) as well as gastrectomy in humans accompanied by vagatomy did not prevent the orexigenic effects of ghrelin treatment, indicating that intact vagus is not required for its orexigenic effects (Adachi et al. 2010). The orexigenic and lipogenic effect of ghrelin provide a potential use of ghrelin antagonists or reverse agonists in the treatment of the obesity (Alvarez-Castro et al. 2013). However, studies in this area have shown conflicting results (Costantini et al. 2011; Abdel-Hakim et al. 2014).

\section{Role of peripheral adiposity signals}

Adiposity signals are signals that inform the brain about the mass of the adipose tissue. Basal levels of insulin and leptin are widely accepted to be adiposity signals. Amylin, ghrelin, and peptide YY have been hypothesized to be adiposity signals (reviewed by Hillebrand and Geary 2010).

Leptin is a peptide hormone produced by the $a b$ gene and secreted mainly by the adipose tissue, playing a key role in the energy homeostasis (Klok et al. 2007). The production of leptin is higher in the subcutaneous than in visceral fat, and its level in the blood correlate directly with the amount of body fat. The secretion of leptin is reduced during periods of fasting and increased after meals. It is influenced by several metabolic and hormonal factors (Friedman 2004).

Leptin is transported across the BBB by a saturable system and exerts its anorectic effect in the ARC via inhibition of NPY/AgRP neurons and activation of POMC/ CART neurons resulting in reduced food intake and increased energy expenditure. The $\mathrm{Ob}-\mathrm{Rb}$ receptor, which is highly expressed in the hypothalamus, is thought to be the main receptor involved in the appetite regulation. $\mathrm{Ob}-\mathrm{Rb}$ receptor belongs to the type I cytokine receptor family and exists in five distinct isoforms (splice variants) named as $\mathrm{Ob}-\mathrm{Ra}$, $\mathrm{Ob}-\mathrm{Rb}, \mathrm{Ob}-\mathrm{Rc}, \mathrm{Ob}-\mathrm{Rd}$, and Ob-Re. Only the Ob-Rb isoform contains a long intracellular domain essential for the biological actions of leptin (Suzuki et al. 2010).

Human obesity is generally associated with high serum levels of leptin and less efficient transport 
across the BBB, consistent with a state of central resistance to leptin. This resistance may be secondary to obesity or vice versa, and genetic factors, age, diet, sedentary lifestyle, and stress might contribute to the development of defects in the transport of leptin across the $\mathrm{BBB}$ or might lead to abnormalities in leptin signaling (Paz-Filho et al. 2009).

Adiponectin and resistin. The adipose tissue produces numerous other factors that may directly or indirectly influence the energy balance and body weight. Adiponectin is one of these factors. The physiological effect of adiponectin is to increase energy expenditure and to protect against insulin resistance and atherosclerosis (Trujillo and Scherer 2006). Studies have shown that adiponectin activates signal transduction pathways similar to leptin and insulin in the hypothalamus, reinforcing its role in the central control of energy homeostasis (Coope et al. 2008). In humans, serum adiponectin levels are inversely related to adiposity and insulin resistance, increasing after weight loss induced by diet or bariatric surgery (Ahima and Lazar 2008). In contrast, resistin is a peptide produced by adipocytes and increases insulin resistance via paracrine actions. Serum levels of resistin are increased in obesity (Banerjee et al. 2004).

Other adipocytokines involved in energy balance. Tumor necrosis factor- $\alpha$ is correlated with the amount of body fat, inhibits feeding, increases metabolic rate, and induces cachexia (Galic et al. 2010). Another potential adipocytokine involved in energy homeostasis is interleukin-6 (IL-6). Several data have suggested a potential protective role of IL- 6 against the development of obesity (Wallenius et al. 2003). However, the data are not consistent between different research groups and the actual involvement of IL- 6 in controlling the energy balance requires additional studies (Ahima and Lazar 2008). In addition, it has been demonstrated that atrial natriuretic peptide (ANP) is expressed and secreted by human preadipocytes. ANP is not only a strong hypotensive, but also a lipolytic compound (Garruti et al. 2008).

\section{Role of catecholamines}

Norepinephrine (NE), synthesized in both the central and peripheral nervous system, is involved in food intake regulation of both mammals and chickens. NPY, a potent orexigenic peptide, is co-localized with NE in the central and peripheral nervous system, suggesting an interaction (Katayama et al. 2010). The effect of NE on the food intake is a point of great controversy. Some studies have demonstrated an increase in the food intake following central NE injec- tion in the anterior and medial hypothalamus, and explained the increase in feeding following ovariectomy by increase in NE (Simpson and Dicara 1973). In contrast, several studies have demonstrated a dosedependent decrease in food intake following ICV injection of NE in rats and chickens (Katayama et al. 2010). Another study evidenced that noradrenergic neurons in the area postrema mediate at least part of the hypophagic action of amylin (Potes et al. 2010).

In the lateral hypothalamus (LH), Leibowitz (1978) has found that epinephrine, NE or dopamine had an anti-feeding effect. Beta-adrenergic or dopaminergic drugs injected into the LH tend to inhibit feeding. Similarly, drugs that release catecholamines also inhibit feeding (Hoebel 1985). Several studies have

Table 1

Summary of central and peripheral orexigenic and anorexigenic hormones/ peptides

\begin{tabular}{llll}
\hline $\begin{array}{l}\text { Orexigenic hormones/ } \\
\text { peptides }\end{array}$ & \multicolumn{2}{l}{$\begin{array}{l}\text { Anorexigenic hormones/ } \\
\text { peptides }\end{array}$} & \\
\hline Central & Peripheral & Central & Peripheral \\
\hline NPY & Ghrelin & POMC & CCK \\
\hline AgRP & & CART & PYY \\
\hline Orexin A & BNDF & PP \\
\hline MCH & ACTH & Enterostatin \\
\hline $\begin{array}{l}\text { Dopamine } \\
\text { "Reward- related } \\
\text { feeding" }\end{array}$ & a-MSH & $\begin{array}{l}\text { Apolipoprotein } \\
\text { A-IV }\end{array}$ \\
\hline $\begin{array}{l}\text { Endogenous } \\
\text { opioids "Reward- } \\
\text { related feeding" }\end{array}$ & Neurotensin & Neurotensin \\
\hline & CRH & GLP-1 \\
\hline & Oxytocin & Oxyntomodulin \\
\hline & TRH & Glucagon \\
\hline & ELABELA & Insulin \\
\hline GALP & Amylin \\
\hline & & Leptin \\
\hline
\end{tabular}

Abbreviations: ACTH - adrenocorticotropic hormone; NPY - neuropeptide Y; AgRP - agouti related peptide; $\mathrm{CRH}$ - corticotrophin releasing hormone; TRH - thyroid releasing hormone; POMC - pro-opiomelanocortin; CART - cocaine-amphetamine regulated transcript; CCK - cholecystokinin; MCH - melanin- concentrating hormone; PYY - peptide tyrosine tyrosine; PP pancreatic polypeptide; GALPn - galanin-like peptide; GLP-1 - glucagon-like peptide 1; BDNF - brain derived neurotrophic factor; $\alpha-\mathrm{MSH}$ - alpha melanocyte stimulating hormone 
suggested that the anorexic action of amphetamine is mediated by releasing of catecholamines in LH (Leibowitz 1978) and so amphetamine loses its effect after killing the catechobamine terminals in the $\mathrm{LH}$ with 6-hydroxydopamine. Without these LH catecholamines the animal a) overeats; b) self-stimulates faster; c) becomes moderately obese, d) is less responsive to amphetamine treatment (Hoebel 1985).

In the medial hypothalamus ( $\mathrm{MH})$, NE input does the opposite. It inhibits the satiety. In front of the $\mathrm{MH}$, the PVN, which lies along the sides of the third ventricle, is the most sensitive site for effect of $\mathrm{NE}$ on feeding where injection of NE or NE mimetics will initiate and also prolong the meal. Amphetamine-induced feeding may sound paradoxically, but it is easily observed and explained when the amphetamine is applied locally into the PVN, where it could inhibit satiety (Leibowitz 1978). Summary of central as well as peripheral orexigenic and anorexigenic hormones/ peptides are shown in Table 1.

\section{Conclusion}

Food intake is controlled centrally by the hypothalamus, brainstem, reward system, and endocannabinoids. The peripheral control of the food intake includes signals from the gastrointestinal tract and adipose tissue. The GIT hormones affecting food intake include ghrelin, an orexigenic peptide that act to increase food intake and anorexigenic hormones that act to decrease food intake and leads to satiation. The agonists for the anorexigenic and antagonist for the orexigenic peptides have been investigated in the treatment of obesity.

\section{References}

Abdel-Hakim SM, Ibrahim MY, Ibrahim HM, Ibrahim MM. The effect of ghrelin antagonist (D-Lys3) GHRP-6 on ovariectomy-induced obesity in adult female albino rats. Endocr Regul 48, 126-134, 2014.

Adachi S, Takiguchi S, Okada K, Yamamoto K, Yamasaki M, Miyata H, Nakajima K, Fujiwara Y, Hosoda H, Kangawa K, Mori M, Doki Y. Effects of ghrelin administration after total gastrectomy: a prospective, randomized, placebo-controlled phase II study. Gastroenterology 138, 1312-1320, 2010.

Ahima RS, Lazar MA. Adipokines and the peripheral and neural control of energy balance. Mol Endocrinol 22, 1023-1031, 2008.

Aja S, Sahandy S, Ladenheim EE, Schwartz GJ, Moran TH. Intracerebroventricular CART peptide reduces food intake and alters motor behavior at a hindbrain site. Am J Physiol Regul Integr Comp Physiol 281, R1862R1867, 2001.

Alen F, Ramirez-Lopez MT, Gomez de Heras R, Rodriguez de Fonseca F, Orio L. Cannabinoid receptors and cholecystokinin in feeding inhibition. Vitam Horm 92, 165-196, 2013.

Alvarez-Castro P, Pena L, Cordido F. Ghrelin in obesity, physiological and pharmacological considerations. Mini Rev Med Chem 13, 541-552, 2013.

Arnold M, Mura A, Langhans W, Geary N. Gut vagal afferents are not necessary for the eating-stimulatory effect of intraperitoneally injected ghrelin in the rat. J Neurosci 26, 11052-11060, 2006.

Baggio LL, Huang Q, Brown TJ, Drucker DJ. Oxyntomodulin and glucagon-like peptide-1 differentially regulate murine food intake and energy expenditure. Gastroenterology 127, 546-558, 2004.

Baggio LL, Drucker DJ. Glucagon-like peptide-1 receptors in the brain: controlling food intake and body weight. J Clin Invest 124, 4223-4226, 2014.

Bagnol D, Lu XY, Kaelin CB, Day HE, Ollmann M, Gantz I, Akil H, Barsh GS, Watson SJ. Anatomy of an endogenous antagonist: relationship between Agouti-related protein and proopiomelanocortin in brain. J Neurosci, 19, RC26, 1999.

Banerjee RR, Rangwala SM, Shapiro JS, Rich AS, Rhoades B, Qi Y, Wang J, Rajala MW, Pocai A, Scherer PE, Steppan CM, Ahima RS, Obici S, Rossetti L, Lazar MA. Regulation of fasted blood glucose by resistin. Science 303, 1195-1198, 2004.

Batterham RL, Le Roux CW, Cohen MA, Park AJ, Ellis SM, Patterson M, Frost GS, Ghatei MA, Bloom SR. Pancreatic polypeptide reduces appetite and food intake in humans. J Clin Endocrinol Metab 88, 3989-3992, 2003.

Benelam B. Satiation, satiety and their effects on eating behaviour. Nutr Bull 34, 126-173, 2009.

Bennetzen MF, Wellner N, Ahmed SS, Ahmed SM, Diep TA, Hansen HS, Richelsen B, Pedersen SB. Investigations of the human endocannabinoid system in two subcutaneous adipose tissue depots in lean subjects and in obese subjects before and after weight loss. Inter J Obes 35, 1377-1384, 2011. 
Bermudez-Silva FJ, Viveros MP, McPartland JM, Rodriguez de Fonseca F. The endocannabinoid system, eating behavior and energy homeostasis: the end or a new beginning? Pharmacol Biochem Behav 95, 375-382, 2010.

Bermudez-Silva FJ, Cardinal P, Cota D. The role of the endocannabinoid system in the neuroendocrine regulation of energy balance. J Psychopharmacol 26, 114-124, 2012.

Bernardis LL, Bellinger LL. The dorsomedial hypothalamic nucleus revisited: 1986 update. Brain Res 434, 321-381, 1987.

Blevins JE, Baskin DG. Translational and therapeutic potential of oxytocin as an anti-obesity strategy: insights from rodents, nonhuman primates and humans. Physiol Behav 152, 438-449, 2015.

Blevins JE, Graham JL, Morton GJ, Bales KL, Schwartz MW, Baskin DG, Havel PJ. Chronic oxytocin administration inhibits food intake, increases energy expenditure, and produces weight loss in fructose-fed obese rhesus monkeys. Am J Physiol Regul Integr Comp Physiol 308, R431-R438, 2015.

Boey D, Lin S, Enriquez RF, Lee NJ, Slack K, Couzens M, Baldock PA, Herzog H, Sainsbury A. PYY transgenic mice are protected against diet-induced and genetic obesity. Neuropeptides 42, 19-30, 2008.

Boguszewski CL, Paz-Filho G, Velloso LA. Neuroendocrine body weight regulation: integration between fat tissue, gastrointestinal tract, and the brain. Endokrynol Pol 61, 194-206, 2010.

Bray GA, York DA. Studies on food intake of genetically obese rats. Am J Physiol 223, 176-179, 1972.

Bray GA, Smith SR, DeJonge L, de Souza R, Rood J, Champagne CM, Laranjo N, Carey V, Obarzanek E, Loria CM, Anton SD, Ryan DH, Greenway FL, Williamson D, Sacks FM. Effect of diet composition on energy expenditure during weight loss: the POUNDS LOST Study. Int J Obes (Lond) 36, 448-455, 2012.

Broberger C, De Lecea L, Sutcliffe JG, Hokfelt T. Hypocretin/Orexin- and melanin-concentrating hormone-expressing cells form distinct populations in the rodent lateral hypothalamus: Relationship to the neuropeptide $\mathrm{Y}$ and agouti gene-related protein systems. J Comp Neurol 402, 460-474, 1998.

Burdyga G, Spiller D, Morris R, Lal S, Thompson DG, Saeed S, Dimaline R, Varro A, Dockray GJ. Expression of the leptin receptor in rat and human nodose ganglion neurones. Neuroscience 109, 339-347, 2002.

Burdyga G, Lal S, Spiller D, Jiang W, Thompson D, Attwood S, Saeed S, Grundy D, Varro A, Dimaline R, Dockray GJ. Localization of orexin-1 receptors to vagal afferent neurons in the rat and humans. Gastroenterology 124, 129-139, 2003.

Cabral GA, Griffin-Thomas L. Emerging role of the cannabinoid receptor CB2 in immune regulation: therapeutic prospects for neuroinflammation. Expert Rev Mol Med 11, e3, 2009.

Castaneda TR, Tong J, Datta R, Culler M, Tschop MH. Ghrelin in the regulation of body weight and metabolism Front Neuroendocrinol 31, 44-60, 2010.

Chen AS, Marsh DJ, Trumbauer ME, Frazier EG, Guan XM, Yu H, Rosenblum CI, Vongs A, Feng Y, Cao L, Metzger JM, Strack AM, Camacho RE, Mellin TN, Nunes CN, Min W, Fisher J, Gopal-Truter S, MacIntyre DE, Chen HY, Van der Ploeg LH. Inactivation of the mouse melanocortin-3 receptor results in increased fat mass and reduced lean body mass. Nat Genet 26, 97-102, 2000.

Cohen MA, Ellis SM, Le Roux CW, Batterham RL, Park A, Patterson M, Frost GS, Ghatei MA, Bloom SR. Oxyntomodulin suppresses appetite and reduces food intake in humans. J Clin Endocrinol Metab 88, 4696-4701, 2003.

Cone RD. Anatomy and regulation of the central melanocortin system. Nat Neurosci 8, 571-578, 2005.

Considine RV, Sinha MK, Heiman ML, Kriauciunas A, Stephens TW, Nyce MR, Ohannesian JP, Marco CC, McKee LJ, Bauer TL. Serum immunoreactive-leptin concentrations in normal-weight and obese humans. New Eng J Med 334, 292-295, 1996.

Coope A, Milanski M, Araujo EP, Tambascia M, Saad MJ, Geloneze B, Velloso LA. AdipoR1 mediates the anorexigenic and insulin/leptin-like actions of adiponectin in the hypothalamus. FEBS Lett 582, 1471-1476, 2008.

Costantini VJ, Vicentini E, Sabbatini FM, Valerio E, Lepore S, Tessari M, Sartori M, Michielin F, Melotto S, Bifone A, Pich EM, Corsi M. GSK1614343, a novel ghrelin receptor antagonist, produces an unexpected increase of food intake and body weight in rodents and dogs. Neuroendocrinol 94, 158-68, 2011.

Cota D, Marsicano G, Tschop M, Grubler Y, Flachskamm C, Schubert M, Auer D, Yassouridis A, Thone-Reineke C, Ortmann S, Tomassoni F, Cervino C, Nisoli E, Linthorst AC, Pasquali R, Lutz B, Stalla GK, Pagotto U. The endogenous cannabinoid system affects energy balance via central orexigenic drive and peripheral lipogenesis. J Clin Invest 112, 423-431, 2003.

Cota D, Tschop MH, Horvath TL, Levine AS. Cannabinoids, opioids and eating behavior: the molecular face of hedonism? Brain Res Rev 51, 85-107, 2006.

Cowley MA, Smith RG, Diano S, Tschop M, Pronchuk N, Grove KL, Strasburger CJ, Bidlingmaier M, Esterman M, Heiman ML, Garcia-Segura LM, Nillni EA, Mendez P, Low MJ, Sotonyi P, Friedman JM, Liu H, Pinto S, Colmers WF, Cone RD, Horvath TL. The distribution and mechanism of action of ghrelin in the CNS demonstrates a novel hypothalamic circuit regulating energy homeostasis. Neuron 37, 649-661, 2003. 
Cummings DE, Overduin J. Gastrointestinal regulation of food intake. J Clin Invest 117, 13-23, 2007.

Dakin CL, Small CJ, Batterham RL, Neary NM, Cohen MA, Patterson M, Ghatei MA, Bloom SR. Peripheral oxyntomodulin reduces food intake and body weight gain in rats. Endocrinol 145, 2687-2695, 2004.

Date Y, Murakami N, Toshinai K, Matsukura S, Niijima A, Matsuo H, Kangawa K, Nakazato M. The role of the gastric afferent vagal nerve in ghrelin induced feeding and growth hormone secretion in rats. Gastroenterology $123,1120-1128,2002$.

Date Y. Ghrelin and the vagus nerve. Methods in Enzymology 514, 261-269, 2012.

de Graaf C, Blom WA, Smeets PA, Stafleu A, Hendriks HF. Biomarkers of satiation and satiety. A J Clin Nutr 79, 946-961, 2004.

Devane WA, Manus L, Breuer A, Pertwee RG, Stevenson LA, Griffin G, Gibson D, Mandelbaum A, Etinger A, Mechoulam R. Isolation and structure of a brain constituent that binds to the cannabinoid receptor. Science 258, 1946-1949, 1992.

Dhuria SV, Fine JM, Bingham D, Svitak AL, Burns RB, Baillargeon AM, Panter SS, Kazi AN, Frey WH 2nd, Hanson LR. Food consumption and activity levels increase in rats following intranasal Hypocretin-1. Neurosci Lett 627, 155-159, 2016.

Di Marzo V, Bisogno T, De Petrocellis L, Melck D, Orlando P, Wagner JA, Kunos G. Biosynthesis and inactivation of the endocannabinoid 2-arachidonoylglycerol in circulating and tumoral macrophages. Eur J Biochem 264, $258-267,1999$.

Di Marzo V, Matias I. Endocannabinoid control of food intake and energy balance. Nat Neurosci 8, 585-589, 2005.

Dube MG, Kalra SP, Kalra PS. Food intake elicited by administration of orexins/hypocretins: identification of hypothalamic sites of action. Brain Res 842, 473-477, 1999.

Fehmann HC, Jiang J, Schweinfurth J, Wheeler MB, Boyd AE 3rd, Goke B. Stable expression of the rat GLP-I receptor in CHO cells: activation and binding characteristics utilizing GLP-I(7-36)-amide, oxyntomodulin, exendin-4, and exendin(9-39). Peptides 15, 453-456, 1994.

Foster-Schubert KE, Cummings DE. Emerging therapeutic strategies for obesity. Endocr Rev 27, 779-793, 2006.

Fraley GS, Scarlett JM, Shimada I, Teklemichael DN, Acohido BV, Clifton DK, Steiner RA. Effects of diabetes and insulin on the expression of Galanin-like peptide in the hypothalamus of the rate. Diabetes 53, 1237-1242, 2004.

Friedman JM. Modern science versus the stigma of obesity. Nat Med 10, 563-569, 2004.

Fujimoto K, Fukagawa K, Sakata T, Tso P. Suppression of food intake by apolipoprotein A-IV is mediated through the central nervous system in rats. J Clin Invest 91, 1830-1833, 1993.

Galic S, Oakhill JS, Steinberg GR. Adipose tissue as an endocrine organ. Mol Cell Endocrinol 316, 129-139, 2010.

Garruti G, Cotecchia S, Giampetruzzi F, Giorgino F, Giorgino R. Neuroendocrine deregulation of food intake, adipose tissue and the gastrointestinal system in obesity and metabolic syndrome. J Gastrointestin Liver Dis 17, 193-198, 2008.

Gauthier KM, Baewer DV, Hittner S, Hillard CJ, Nithipatikom K, Reddy DS, Falck JR, Campbell WB. Endotheliumderived 2-arachidonylglycerol: an intermediate in vasodilatory eicosanoid release in bovine coronary arteries. Am J Physiol Heart Circ Physiol 288, H1344-H1351, 2005.

Geary N, Le Sauter J, Noh U. Glucagon acts in the liver to control spontaneous meal size in rats. Am J Physiol 264, R116-R122, 1993.

Gerozissis K. Brain insulin and feeding: a bi-directional communication. Eur J Pharmacol 490, 59-70, 2004.

Ghatei MA, Uttenthal LO, Christofides ND, Bryant MG, Bloom SR. Molecular forms of human enteroglucagon in tissue and plasma: plasma responses to nutrient stimuli in health and in disorders of the upper gastrointestinal tract. J Clin Endocrinol Metab 57, 488-495, 1983.

Gonthier MP, Hoareau L, Festy F, Matias I, Valenti M, Bes-Houtmann S, Rouch C, Robert-Da Silva C, Chesne S, Lefebvre d'Hellencourt C, Cesari M, Di Marzo V, Roche R. Identification of endocannabinoids and related compounds in human fat cells. Obesity 15, 837-845, 2007.

Goodman A. Neurobiology of addiction. An integrative review. Biochem Pharmacol 75, 266-322, 2008.

Halmos T, Suba I. Role of the brain in the regulation of metabolism and energy expenditure: the central role of insulin, and insulin resistance of the brain. Orv Hetil 152, 83-91, 2011.

Hankir MK, Parkinson JR, Minnion JS, Addison ML, Bloom SR, Bell JD. Peptide YY 3-36 and pancreatic polypeptide differentially regulate hypothalamic neuronal activity in mice in vivo as measured by manganese-enhanced magnetic resonance imaging. J Neuroendocrinol 23, 371-380, 2011.

Hare KJ. Role of GLP-1 induced glucagon suppression in type 2 diabetes mellitus. Dan Med Bull 57, B4181, 2010.

Hargrave SL, Kinzig KP. Repeated gastric distension alters food intake and neuroendocrine profiles in rats. Physiol Behav 105, 975-981, 2012. 
Herisson FM, Waas JR, Fredriksson R, Schioth HB, Levine AS, Olszewski PK. Oxytocin acting in the nucleus accumbens core decreases food intake. J Neuroendocrinol 28, 2016.

Hillebrand JJ, Geary N. Do leptin and insulin signal adiposity? Forum Nutr 63, 111-122, 2010.

Hirako S, Wada N, Kageyama H, Takenoya F, Izumida Y, Kim H, Iizuka Y, Matsumoto A, Okabe M, Kimura A, Suzuki M, Yamanaka S, Shioda S. Autonomic nervous system-mediated effects of galanin-like peptide on lipid metabolism in liver and adipose tissue. Sci Rep 6, 21481, 2016.

Hoebel BG. Brain neurotransmitters in food and drug reward. Am J Clin Nutr 42, 1133-1150, 1985.

Holst JJ. On the physiology of GIP and GLP-1. Horm Metab Res 36, 747-754, 2004.

Honda K, Kamisoyama H, Saito N, Kurose Y, Sugahara K, Hasegawa S. Central administration of glucagon suppresses food intake in chicks. Neurosci Lett 416, 198-201, 2007.

Horvath TL. Endocannabinoids and the regulation of body fat: the smoke is clearing. J Clin Invest 112, 323-326, 2003.

Hotta M, Shibasaki T, Arai K, Demura H. Corticotropin-releasing factor receptor type 1 mediates emotional stressinduced inhibition of food intake and behavioral changes in rats. Brain Res 823, 221-225, 1999.

Hou J, Zheng DZ, Zhou JY, Zhou SW. Orexigenic effect of cocaine- and amphetamine-regulated transcript (CART) after injection into hypothalamic nuclei in streptozotocin-diabetic rats. Clin Exp Pharmacol Physiol 37, 989-995, 2010.

Huszar D, Lynch CA, Fairchild-Huntress V, Dunmore JH, Fang Q, Berkemeier LR, Gu W, Kesterson RA, Boston BA, Cone RD, Smith FJ, Campfield LA, Burn P, Lee F. Targeted disruption of the melanocortin-4 receptor results in obesity in mice. Cell 88, 131-134, 1997.

Iwasaki Y, Kakei M, Nakabayashi H, Ayush EA, Hirano-Kodaira M, Maejima Y, Yada T. Pancreatic polypeptide and peptide YY3-36 induce Ca2+ signaling in nodose ganglion neurons. Neuropeptides 47, 19-23, 2013.

Jamshidi N, Taylor DA. Anandamide administration into the ventromedial hypothalamus stimulates appetite in rats. Br J Pharmacol 134, 1151-1154, 2001.

Jbilo O, Ravinet-Trillou C, Arnone M, Buisson I, Bribes E, Peleraux A, Penarier G, Soubrie P, Le Fur G, Galiegue S, Casellas $\mathrm{P}$. The CB1 receptor antagonist rimonabant reverses the diet-induced obesity phenotype through the regulation of lipolysis and energy balance. FASEB J19, 1567-1569, 2005.

Jequier E, Tappy L. Regulation of body weight in humans. Physiol Rev 79, 451-480, 1999.

Jesudason DR, Monteiro MP, McGowan BM, Neary NM, Park AJ, Philippou E, Small CJ, Frost GS, Ghatei MA, Bloom SR. Low-dose pancreatic polypeptide inhibits food intake in man. Br J Nutr 97, 426-429, 2007.

Kageyama H, Shiba K, Hirako S, Wada N, Yamanaka S, Nogi Y, Takenoya F, Nonaka N, Hirano T, Inoue S, Shioda S. Anti-obesity effect of intranasal administration of galanin-like peptide (GALP) in obese mice. Sci Rep 6, 28200, 2016.

Katayama S, Tomonaga S, Sato M, Yamane H, Tsuneyoshi Y, Denbow DM, Furuse M. Norepinephrine does not alter NPY and POMC mRNA expression in neonatal chicks. Comp Biochem Physiol A Mol Integr Physiol 156, 143-146, 2010.

Keenan GS, Brunstrom JM, Ferriday D. Effects of meal variety on expected satiation: evidence for a 'perceived volume' heuristic. Appetite 89, 10-15, 2015.

Kenny PJ. Common cellular and molecular mechanisms in obesity and drug addiction. Nat Rev Neurosci 12, 638651, 2011.

Kim ER, Mizuno TM. Role of neurotensin receptor 1 in the regulation of food intake by neuromedins and neuromedin-related peptides. Neurosci Lett 468, 64-67, 2010.

Klok MD, Jakobsdottir S, Drent ML. The role of leptin and ghrelin in the regulation of food intake and body weight in humans: a review. Obes Rev 8, 21-34, 2007.

Kogan NM, Mechoulam R. The chemistry of endocannabinoids. J Endocrinol Invest 29, 3-14, 2006.

Kola B, Farkas I, Christ-Crain M, Wittmann G, Lolli F, Amin F, Harvey-White J, Liposits Z, Kunos G, Grossman AB, Fekete C, Korbonits M. The orexigenic effect of ghrelin is mediated through central activation of the endogenous cannabinoid system. PLoS One 3, e1797, 2008.

Koren MS, Holmes MD. Vagus nerve stimulation does not lead to significant changes in body weight in patients with epilepsy. Epilepsy Behav 8, 246-249, 2006.

Kristensen P, Judge ME, Thim L, Ribel U, Christjansen KN, Wulff BS, Clausen JT, Jensen PB, Madsen OD, Vrang N, Larsen PJ, Hastrup S. Hypothalamic CART is a new anorectic peptide regulated by leptin. Nature 393, 72-76, 1998.

Krude H, Biebermann H, Luck W, Horn R, Brabant G, Gruters A. Severe early-onset obesity, adrenal insufficiency and red hair pigmentation caused by POMC mutations in humans. Nat Genet 19, 155-157, 1998. 
Lateef DM, Washington MC, Raboin SJ, Roberson AE, Mansour MM, Williams CS, Sayegh AI. Duodenal myotomy blocks reduction of meal size and prolongation of intermeal interval by cholecystokinin. Physiol Behav 105, 829-834, 2012.

Lawrence C, Fraley GS. Galanin-like peptide (GALP) is a hypothalamic regulator of energy homeostasis and reproduction. Front Neuroendocrinol 32, 1-9, 2011.

Lawson EA, Marengi DA, DeSanti RL, Holmes TM, Schoenfeld DA, Tolley CJ. Oxytocin reduces caloric intake in men. Obesity (Silver Spring) 23, 950-956, 2015.

le Roux CW, Batterham RL, Aylwin SJ, Patterson M, Borg CM, Wynne KJ, Kent A, Vincent RP, Gardiner J, Ghatei MA, Bloom SR. Attenuated peptide YY release in obese subjects is associated with reduced satiety. Endocrinology 147, 3-8, 2006.

Lee H K, Choi EB, Pak CS. The current status and future perspectives of studies of cannabinoid receptor 1 antagonists as anti-obesity agents. Curr Top Med Chem 9, 482-503, 2009.

Leibowitz SF. Paraventricular nucleus: a primary site mediating adrenergic stimulation of feeding and drinking. Pharmacol Biochem Behav 8, 163-175, 1978.

Liddle RA, Goldfine ID, Rosen MS, Taplitz RA, Williams JA. Cholecystokinin bioactivity in human plasma. Molecular forms, responses to feeding, and relationship to gallbladder contraction. J Clin Invest 75, 1144-1152, 1985.

Lin S, Boey D, Herzog H. NPY and Y receptors: lessons from transgenic and knockout models. Neuropeptides 38, 189-200, 2004.

Lin S, Shi YC, Yulyaningsih E, Aljanova A, Zhang L, Macia L, Nguyen AD, Lin EJ, During MJ, Herzog H, Sainsbury A. Critical role of arcuate Y4 receptors and the melanocortin system in pancreatic polypeptide-induced reduction in food intake in mice. PLoS One 4, e8488, 2009.

Little TJ, Pilichiewicz AN, Russo A, Phillips L, Jones KL, Nauck MA, Wishart J, Horowitz M, Feinle-Bisset C. Effects of intravenous glucagon-like peptide-1 on gastric emptying and intragastric distribution in healthy subjects: relationships with postprandial glycemic and insulinemic responses. J Clin Endocrinol Metab 91, 1916-1923, 2006.

Lutz TA. Control of food intake and energy expenditure by amylin-therapeutic implications. Int J Obes (Lond) 33, S24-S27, 2009.

Maejima T, Hashimoto K, Yoshida T, Aiba A, Kano M. Presynaptic inhibition caused by retrograde signal from metabotropic glutamate to cannabinoid receptors. Neuron 31, 463-475, 2001.

Martin CK, Bellanger DE, Rau KK, Coulon S, Greenway FL. Safety of the Ullorex oral intragastric balloon for the treatment of obesity. J Diabetes Sci Technol 1, 574-581, 2007.

Martin KA, Mani MV, Mani A. New targets to treat obesity and the metabolic syndrome. Eur J Pharmacol 763, 64-74, 2015.

Mastorakos G, Zapanti E. The hypothalamic-pituitary-adrenal axis in the neuroendocrine regulation of food intake and obesity: the role of corticotropin releasing hormone. Nutr Neurosci 7, 271-280, 2004.

Matias I, Bisogno T, Di Marzo V. Endogenous cannabinoids in the brain and peripheral tissues: regulation of their levels and control of food intake. Int J Obes (Lond) 30, S7-S12, 2006.

Matsuda K, Kojima K, Shimakura S, Wada K, Maruyama K, Uchiyama M, Kikuyama S, Shioda S. Corticotropinreleasing hormone mediates a-melanocyte-stimulating hormone-induced anorexigenic action in goldfish. Peptides 29, 1930-1936, 2008.

McGowan MK, Andrews KM, Grossman SP. Chronic intrahypothalamic infusions of insulin or insulin antibodies alter body weight and food intake in the rat. Physiol Behav 51, 753-766, 1992.

Mechoulam R, Ben-Shabat S, Hanus L, Ligumsky M, Kaminski NE, Schatz AR, Gopher A, Almog S, Martin BR, Compton DR, Pertwee RG, Griffin G, Bayewitch M, Barg J, Vogel Z. Identification of an endogenous 2-monoglyceride present in canine gut, that binds to cannabinoid receptors. Biochem Pharmacol 50, 83-90, 1995.

Meguid MM, Glade MJ, Middleton FA. Weight regain after Roux-en-Y: a significant 20\% complication related to PYY. Nutrition 24, 832-842, 2008.

Mentlein R, Gallwitz B, Schmidt WE. Dipeptidyl-peptidase IV hydrolyses gastric inhibitory polypeptide, glucagonlike peptide-1(7-36) amide, peptide histidine methionine and is responsible for their degradation in human serum. Eur J Biochem 214, 829-835, 1993.

Meyer-Lindenberg A, Domes G, Kirsch P, Heinrichs M. Oxytocin and vasopressin in the human brain: social neuropeptides for translational medicine. Nat Rev Neurosci 12, 524-538, 2011.

Mihaly E, Fekete C, Legradi G, Lechan RM. Hypothalamic dorsomedial nucleus neurons innervate thyrotropinreleasing hormone- synthesizing neurons in the paraventricular nucleus. Brain Res 891, 20-31, 2001. 
Moore CJ, Johnson ZP, Higgins M, Toufexis D, Wilson ME. Antagonism of corticotrophin-releasing factor type 1 receptors attenuates caloric intake of free feeding subordinate female rhesus monkeys in a rich dietary environment. J Neuroendocrinol 27, 33-43, 2015.

Moran TH, Baldessarini AR, Salorio CF, Lowery T, Schwartz GJ. Vagal afferent and efferent contributions to the inhibition of food intake by cholecystokinin. Am J Physiol 272, R1245-R1251, 1997.

Moran TH, Katz LF, Plata-Salaman CR, Schwartz GJ. Disordered food intake and obesity in rats lacking cholecystokinin A receptors. Am J Physiol 274, R618-R625, 1998.

Moriarty P, Dimaline R, Thompson DG, Dockray GJ. Characterization of cholecystokininA and cholecystokininB receptors expressed by vagal afferent neurons. Neuroscience 79, 905-913, 1997.

Morton GJ, Thatcher BS, Reidelberger RD, Ogimoto K, Wolden-Hanson T, Baskin DG, Schwartz MW, Blevins JE. Peripheral oxytocin suppresses food intake and causes weight loss in diet-induced obese rats. Am J Physiol Endocrinol Metab 302, E134-E144, 2012.

Nakagawa A, Satake H, Nakabayashi H, Nishizawa M, Furuya K, Nakano S, Kigoshi T, Nakayama K, Uchida K. Receptor gene expression of glucagon-like peptide-1, but not glucose-dependent insulinotropic polypeptide, in rat nodose ganglion cells. Auton Neurosci 110, 36-43, 2004.

Nelson DW, Sharp JW, Brownfield MS, Raybould HE, Ney DM. Localization and activation of glucagon-like peptide-2 receptors on vagal afferents in the rat. Endocrinology 148, 1954-1962, 2007.

Nogueiras R, Veyrat-Durebex C, Suchanek PM, Klein M, Tschop J, Caldwell C, Woods SC, Wittmann G, Watanabe M, Liposits Z, Fekete C, Reizes O, Rohner-Jeanrenaud F, Tschop MH. Peripheral, but not central, CB1 antagonism provides food intake-independent metabolic benefits in diet-induced obese rats. Diabetes 57, 2977-2991, 2008.

Nutt DJ, Lingford-Hughes A, Erritzoe D, Stokes PR. The dopamine theory of addiction: 40 years of highs and lows. Nat Rev Neurosci 16, 305-312, 2015.

Ochner CN, Barrios DM, Lee CD, Pi-Sunyer FX. Biological mechanisms that promote weight regain following weight loss in obese humans. Physiol Behav 15, 106-113, 2013.

Okada S, York DA, Bray GA, Mei J, Erlanson-Albertsson C. Differential inhibition of fat intake in two strains of rat by the peptide enterostatin. Am J Physiol 262, R1111-R1116, 1992.

Ott V, Finlayson G, Lehnert H, Heitmann B, Heinrichs M, Born J, Hallschmid M. Oxytocin reduces reward-driven food intake in humans. Diabetes 62, 3418-3425, 2013.

Overduin J, Gibbs J, Cummings DE, Reeve JR Jr. CCK-58 elicits both satiety and satiation in rats while CCK- 8 elicits only satiation. Peptides 54, 71-80, 2014.

Pagano C, Rossato M, Vettor R. Endocannabinoids, adipose tissue and lipid metabolism. J Neuroendocrinol 20, 124-129, 2008.

Pagotto U, Marsicano G, Cota D, Lutz B, Pasquali R. The emerging role of the endocannabinoid system in endocrine regulation and energy balance. Endocr Rev 27, 73-100, 2006.

Palmiter RD. Is dopamine a physiologically relevant mediator of feeding behavior? Trends Neurosci 30, 375-381, 2007.

Parker JA, McCullough KA, Field BC, Minnion JS, Martin NM, Ghatei MA, Bloom SR. Glucagon and GLP-1 inhibit food intake and increase c-fos expression in similar appetite regulating centres in the brainstem and amygdala. Int J Obes (Lond) 37, 1391-1398, 2013.

Paz-Filho GJ, Volaco A, Suplicy HL, Radominski RB, Boguszewski CL. Decrease in leptin production by the adipose tissue in obesity associated with severe metabolic syndrome. Arq Bras Endocrinol Metabol 53, 1088-1095, 2009.

Pelleymounter MA, Cullen MJ, Wellman CL. Characteristics of BDNF-induced weight loss. Exp Neurol 131, 229238, 1995.

Pfluger PT, Kampe J, Castaneda TR, Vahl T, D’Alessio DA, Kruthaupt T, Benoit SC, Cuntz U, Rochlitz HJ, Moehlig M, Pfeiffer AF, Koebnick C, Weickert MO, Otto B, Spranger J, Tschop MH. Effect of human body weight changes on circulating levels of peptide YY and peptide YY3-36. J Clin Endocrinol Metab 92, 583-588, 2007.

Pocai A, Carrington PE, Adams JR, Wright M, Eiermann G, Zhu L, Du X, Petrov A, Lassman ME, Jiang G, Liu F, Miller C, Tota LM, Zhou G, Zhang X, Sountis MM, Santoprete A, Capito’ E, Chicchi GG, Thornberry N, Bianchi E, Pessi A, Marsh DJ, SinhaRoy R. Glucagon-like peptide 1/glucagon receptor dual agonism reverses obesity in mice. Diabetes 58, 2258-2266, 2009.

Pomorska DK, do-Rego JC, do-Rego JL, Zubrzycka M, Janecka A. Opioid and cannabinoid system in food intake. Curr Pharm Des 22, 1361-1370, 2016.

Potes CS, Turek VF, Cole RL, Vu C, Roland BL, Roth JD, Riediger T, Lutz TA. Noradrenergic neurons of the area postrema mediate amylin's hypophagic action. Am J Physiol Regul Integr Comp Physiol 299, R623-R631, 2010. 
Pothos EN, Hernandez L, Hoebel BG. Chronic food deprivation decreases extracellular dopamine in the nucleus accumbens: implications for a possible neurochemical link between weight loss and drug abuse. Obes Res 3, 525S-529S, 1995.

Powley TL, Chi MM, Baronowsky EA, Phillips RJ. Gastrointestinal tract innervation of the mouse: afferent regeneration and meal patterning after vagotomy. Am J Physiol Regul Integr Comp Physiol 289, R563-R574, 2005.

Qin X, Tso P. The role of apolipoprotein AIV in the control of food intake. Curr Drug Targets 6, 145-151, 2005.

Quarta C, Bellocchio L, Mancini G, Mazza R, Cervino C, Braulke LJ, Fekete C, Latorre R, Nanni C, Bucci M, Clemens LE, Heldmaier G, Watanabe M, Leste-Lassere T, Maitre M, Tedesco L, Fanelli F, Reuss S, Klaus S, Srivastava RK, Monory K, Valerio A, Grandis A, De Giorgio R, Pasquali R, Nisoli E, Cota D, Lutz B, Marsicano G, Pagotto U. CB(1) signaling in forebrain and sympathetic neurons is a key determinant of endocannabinoid actions on energy balance. Cell Metab 11, 273-285, 2010.

Quarta C, Mazza R, Obici S, Pasquali R, Pagotto U. Energy balance regulation by endocannabinoids at central and peripheral levels. Trends Mol Med 17, 518-526, 2011.

Raffan E, Dennis RJ, O’Donovan CJ, Becker JM, Scott RA, Smith SP, Withers DJ, Wood CJ, Conci E, Clements DN, Summers KM, German AJ, Mellersh CS, Arendt ML, Iyemere VP, Withers E, Soder J, Wernersson S, Andersson G, Lindblad-Toh K, Yeo GS, O’Rahilly S. A Deletion in the canine POMC gene is associated with weight and appetite in obesity-prone labrador retriever dogs. Cell Metab 23, 893-900, 2016.

Ratner C, Skov LJ, Raida Z, Bachler T, Bellmann-Sickert K, Le Foll C, Sivertsen B, Dalboge LS, Hartmann B, BeckSickinger AG, Madsen AN, Jelsing J, Holst JJ, Lutz TA, Andrews ZB, Holst B. Effects of peripheral neurotensin on appetite regulation and its role in gastric bypass surgery. Endocrinology 157, 3482-3492, 2016.

Ravinet Trillou C, Delgorge C, Menet C, Arnone M, Soubrie P. CB1 cannabinoid receptor knockout in mice leads to leanness, resistance to diet induced obesity and enhanced leptin sensitivity. Int J Obes Relat Metab Disord $28,640-648,2004$.

Rehfeld JF. The new biology of gastrointestinal hormones. Physiol Rev 78, 1087-1108, 1998.

Riedy CA, Chavez M, Figlewicz DP, Woods SC. Central insulin enhances sensitivity to cholecystokinin. Physiol Behav 58, 755-760, 1995.

Ritter RC. Gastrointestinal mechanisms of satiation for food. Physiol Behav 81, 249-273, 2004.

Rohner-Jeanrenaud F, Craft LS, Bridwell J, Suter TM, Tinsley FC, Smiley DL, Burkhart DR, Statnick MA, Heiman ML, Ravussin E, Caro JF. Chronic central infusion of cocaine- and amphetamine-regulated transcript (CART 55-102): effects on body weight homeostasis in lean and high-fat-fed obese rats. Int J Obes Relat Metab Disord 26, 143-149, 2002.

Rorato R, Miyahara C, Antunes-Rodrigues J, Elias LL. Tolerance to hypophagia induced by prolonged treatment with a $\mathrm{CB} 1$ antagonist is related to the reversion of anorexigenic neuropeptide gene expression in the hypothalamus. Regul Pept 182, 12-18, 2013.

Roth JD, Hughes H, Kendall E, Baron AD, Anderson CM. Antiobesity effects of the beta-cell hormone amylin in diet-induced obese rats: effects on food intake, body weight, composition, energy expenditure, and gene expression. Endocrinology 147, 5855-5864, 2006.

Sandoval D, Cota D, Seeley RJ. The integrative role of CNS fuel-sensing mechanisms in energy balance and glucose regulation. Annu Rev Physiol 70, 513-535, 2008.

Santoso P, Maejima Y, Kumamoto K, Takenoshita S, Shimomura K. Central action of ELABELA reduces food intake and activates arginine vasopressin and corticotropin-releasing hormone neurons in the hypothalamic paraventricular nucleus. Neuroreport 26, 820-826, 2015.

Sawchenko PE, Swanson LW. Localization, localization, and plasticity of corticotropin-releasing factor immunoreactivity in rat brain. Fed Proc 44, 221-227, 1985.

Scheen AJ, Van Gaal LG, Despres JP, Pi-Sunyer X, Golay A, Hanotin C. Rimonabant improves cardiometabolic risk profile in obese or overweight subjects: overview of RIO studies. Rev Med Suisse 2, 1916-1923, 2006.

Schwartz GJ. The role of gastrointestinal vagal afferents in the control of food intake: current prospects. Nutrition 16, 866-873, 2000.

Schwartz GJ. Brainstem integrative function in the central nervous system control of food intake. Forum Nutr 63, 141-151, 2010.

Sekino A, Ohata H, Mano-Otagiri A, Arai K, Shibasaki T. Both corticotropin-releasing factor receptor type 1 and type 2 are involved in stress-induced inhibition of food intake in rats. Psychopharmacology 176, 30-38, 2004.

Silvestri C, Di Marzo V. The endocannabinoid system in energy homeostasis and the etiopathology of metabolic disorders. Cell Metab 17, 475-490, 2013. 
Simpson CW, Dicara L. Estradiol Inhibition of Catecholamine Elicited Eating in the Female Rat. Pharmacol Biochem Behav 1, 413-419, 1973.

Smith GP. Satiation: from gut to brain. Oxford University Press, New York, USA. PP 291, 1998.

Sterl K, Wang S, Oestricker L, Wallendorf MJ, Patterson BW, Reeds DN, Wice BM. Metabolic responses to xenin-25 are altered in humans with Roux-en-Y gastric bypass surgery. Peptides 82, 76-84, 2016.

Strubbe JH, Woods SC. The timing of meals. Psychol Rev 111, 128-141, 2004.

Sun Y, Wang P, Zheng H, Smith RG. Ghrelin stimulation of growth hormone release and appetite is mediated through the growth hormone secretagogue receptor. Proc Natl Acad Sci U S A 101, 4679-4684, 2004.

Suzuki K, Simpson K A, Minnion JS, Shillito JC, Bloom SR. The role of gut hormones and the hypothalamus in appetite regulation. Endocrinol J 57, 359-372, 2010.

Takenoya F, Hirayama M, Kageyama H, Funahashi H, Kita T, Matsumoto H, Ohtaki T, Katoh S, Takeuchi M, Shioda S. Neuronal interactions between galanin-like-peptide- and orexin- or melanin-concentrating hormonecontaining neurons. Regul Pept 126, 79-83, 2005.

Talsania T, Anini Y, Siu S, Drucker DJ, Brubaker PL. Peripheral exendin-4 and peptide YY (3-36) synergistically reduce food intake through different mechanisms in mice. Endocrinology 146, 3748-3756, 2005.

Tam J, Vemuri VK, Liu J, Batkai S, Mukhopadhyay B, Godlewski G, Osei-Hyiaman D, Ohnuma S, Ambudkar SV, Pickel J, Makriyannis A, Kunos G. Peripheral CB1 cannabinoid receptor blockade improves cardiometabolic risk in mouse models of obesity. J Clin Invest 120, 2953-6629, 2010.

Tanda G, Di Chiara G. A dopamine- $\bigotimes 1$ opioid link in the rat ventral tegmentum shared by palatable food (Fonzies) and non-psychostimulant drugs of abuse. Eur J Neurosci 10, 1179-1187, 1998.

Tedesco L, Valerio A, Cervino C, Cardile A, Pagano C, Vettor R, Pasquali R, Carruba MO, Marsicano G, Lutz B, Pagotto U, Nisoli E. Cannabinoid type 1 receptor blockade promotes mitochondrial biogenesis through endothelial nitric oxide synthase expression in white adipocytes. Diabetes 57, 2028-2036, 2008.

Thienel M, Fritsche A, Heinrichs M, Peter A, Ewers M, Lehnert H, Born J, Hallschmid M. Oxytocin's inhibitory effect on food intake is stronger in obese than normal-weight men. Int J Obes (Lond) 40, 1707-1714, 2016.

Trujillo ME, Scherer PE. Adipose tissue-derived factors: impact on health and disease. Endocr Rev 27, 762-778, 2006.

Tso P, Sun W, Liu M. Gastrointestinal satiety signals IV. Apolipoprotein A-IV. Am J Physiol Gastrointest Liver Physiol 286, G885-G890, 2004.

Verty AN, McGregor IS, Mallet PE. Paraventricular hypothalamic CB (1) cannabinoid receptors are involved in the feeding stimulatory effects of Delta (9)-tetrahydrocannabinol. Neuropharmacology 49, 1101-1109, 2005.

Verty AN, Boon WM, Mallet PE, McGregor IS, Oldfield BJ. Involvement of hypothalamic peptides in the anorectic action of the CB receptor antagonist rimonabant (SR 141716). Eur J Neurosci 29, 2207-2216, 2009.

Verty AN, Stefanidis A, McAinch AJ, Hryciw DH, Oldfield B. Anti-obesity effect of the CB2 receptor agonist JWH015 in diet-induced obese mice. PLoS One 10, e0140592, 2015.

Volkow ND, Wang GJ, Baler RD. Reward, dopamine and the control of food intake: implications for obesity. Trends Cogn Sci 15, 37-46, 2011.

Wallenius K, Jansson JO, Wallenius V. The therapeutic potential of interleukin-6 in treating obesity. Expert Opin Biol Ther 3, 1061-1070, 2003.

Washington MC, Coggeshall J, Sayegh AI. Cholecystokinin-33 inhibits meal size and prolongs the subsequent intermeal interval. Peptides 32, 971-977, 2011.

Whitcomb DC, Puccio AM, Vigna SR, Taylor IL, Hoffman GE. Distribution of pancreatic polypeptide receptors in the rat brain. Brain Res 760, 137-149, 1997.

Wielinga PY, Alder B, Lutz TA. The acute effect of amylin and salmon calcitonin on energy expenditure. Physiol Behav 91, 212-217, 2007.

Wodowska J, Ciosek J. [Galanin-like peptide (GALP): localization, receptors and biological function]. Postepy Hig Med Dosw (Online) 69, 1067-1076, 2015.

Woods SC, Lotter EC, McKay LD, Porte D Jr. Chronic intracerebroventricular infusion of insulin reduces food intake and body weight of baboons. Nature 282, 503-505, 1979.

Woods SC, Seeley RJ, Baskin DG, Schwartz MW. Insulin and the blood-brain barrier. Curr Pharm Des 9, 795-800, 2003.

Woods SC. Signals that influence food intake and body weight. Physiol Behav 86, 709-716, 2005.

Wynne K, Stanley S, McGowan B, Bloom S. Appetite control. J Endocrinol 184, 291-318, 2005.

Wynne K, Park AJ, Small CJ, Meeran K, Ghatei MA, Frost GS, Bloom SR. Oxyntomodulin increases energy expenditure in addition to decreasing energy intake in overweight and obesehumans: a randomized controlled trial. Int J Obes (Lond) 30, 1729-1736, 2006. 
Xu B, Goulding EH, Zang K, Cepoi D, Cone RD, Jones KR, Tecott LH, Reichardt LF. Brain-derived neurotrophic factor regulates energy balance downstream of melanocortin-4 receptor. Nat Neurosci 6, 736-742, 2003.

Young A, Denaro M. Roles of amylin in diabetes and in regulation of nutrient load. Nutrition 14, 524-527, 1998.

Yu Y, South T, Wang Q, Huang XF. Differential expression of hypothalamic CART mRNA in response to body weight change following different dietary interventions. Neurochem Int 52, 1422-1430, 2008.

Zac-Varghese S, Tan T, Bloom SR. Hormonal interactions between gut and brain. Discov Med 10, 543-552. 2010.

Zhang H, Wu C, Chen Q, Chen X, Xu Z, Wu J, Cai D. Treatment of obesity and diabetes using oxytocin or analogs in patients and mouse models. PLoS One 8, e61477, 2013. 